\title{
Increasing the oral bioavailability of poorly water-soluble carbamazepine using immediate-release pellets supported on SBA- I 5 mesoporous silica [Erratum]
}

Increasing the oral bioavailability of poorly watersoluble carbamazepine using immediate-release pellets supported on SBA-15 mesoporous silica Wang Z, Chen B, Quan G, et al. International Journal of Nanomedicine. 2012;7:5807-5818.

This paper was published without the Supplementary materials.

Supplementary materials

1: http://youtu.be/ialR9Yx7Hng

2: http://youtu.be/3v2 jqKsvBhw

3: http://youtu.be/YYfQVgjkMIM

4. http://youtu.be/IAfkI8TyuvU

5. http://youtu.be/s.Jhw-DYlj30

International Journal of Nanomedicine

\section{Publish your work in this journal}

The International Journal of Nanomedicine is an international, peerreviewed journal focusing on the application of nanotechnology in diagnostics, therapeutics, and drug delivery systems throughou the biomedical field. This journal is indexed on PubMed Central, MedLine, CAS, SciSearch ${ }^{\circledR}$, Current Contents ${ }^{\circledR} /$ Clinical Medicine,
Journal Citation Reports/Science Edition, EMBase, Scopus and the Elsevier Bibliographic databases. The manuscript management system is completely online and includes a very quick and fair peer-review system, which is all easy to use. Visit http://www.dovepress.com/ testimonials.php to read real quotes from published authors. submit your manuscript | www.dovepress.com

Dovepress

http://dx.doi/org//0.2147/IJN.S41619
International Journal of Nanomedicine 2013:8 627

(C) 20I 3 Wang et al, publisher and licensee Dove Medical Press Ltd. This is an Open Access article which permits unrestricted noncommercial use, provided the original work is properly cited. 